\title{
Soil moisture conservation practices on growth and yield of cotton under rainfed conditions of Tamil Nadu
}

VIVEK S. DEVARANAVADAGI AND S. SANTHANA BOSU

Received : 09.08.2017; Revised : 07.09.2017; Accepted : 22.09.2017

See end of the Paper for authors' affiliation

Correspondence to :

VIVEK S.

DEVARANAVADAGI

Agricultural Research Station,

Mudhol, BAGALKOT

(KARNATAKA) INDIA

Email : vivdev2@gmail.com
- ABSTRACT : A field experiment was conducted at Cotton Research Station, Veppanthattai, Perambalur district of Tamil Nadu between October 2012 to March 2013 to study the effect of different in situ moisture conservation practices on cotton. The main plot treatments (4) comprised of summer ploughing + harrowing, chisel ploughing + harrowing, summer ploughing + chisel ploughing + harrowing and incorporating coir pith ( 5 tons/ha) by coir pith applicator. The subplot treatments (5) included broad bed furrow, ridges and furrow, random tied ridging, basin listing and conventional method. Significantly higher and consistent availability of soil moisture (9.4-29.1\%) was recorded by incorporating coir pith using coir pith applicator as compared to other main plot treatments and among subplots, broad bed furrow conserved higher soil moisture $(29.5 \%)$ followed by ridges and furrows $(27.2 \%)$. Maximum plant height $(142.3 \mathrm{~cm})$ and dry matter production (4632.0 $\mathrm{kg} / \mathrm{ha}$ ) was observed in coir pith application with broad bed furrow treatment. Broad bed furrow increased the yield by $19.23 \%(2167.5 \mathrm{~kg} / \mathrm{ha})$ over the control. Hence coir pith application with broad bed furrow is found to be the best practice for enhanced soil moisture availability as compared to other conservation practices for deep clay soils.

- KEY WORDS : In situ moisture conservation, Deep clay soils, Cotton, Broad bed furrow, Coir pith application

- HOW TO CITE THIS PAPER : Devaranavadagi, Vivek S. and Bosu, S. Santhana (2017). Soil moisture conservation practices on growth and yield of cotton under rainfed conditions of Tamil Nadu. Internat. J. Agric. Engg., 10(2) : 612-618, DOI: 10.15740/HAS/IJAE/10.2/612-618. 